TITLE:

\title{
Phycological Observations-III. ON THE OCCURRENCE OF GENUS ACTINOTRICHIA IN THE PHILIPPINES
}

\section{$\operatorname{AUTHOR(S):~}$}

Cordero, Paciente A.

\section{CITATION:}

Cordero, Paciente A.. Phycological Observations-III. ON THE OCCURRENCE OF GENUS ACTINOTRICHIA IN THE PHILIPPINES. PUBLICATIONS OF THE SETO MARINE BIOLOGICAL LABORATORY 1975, 22(5): 267-276

ISSUE DATE:

1975-11-29

URL:

http://hdl.handle.net/2433/175902

RIGHT: 


\title{
Phycological Observations-III. ON THE OCGURRENCE OF GENUS ACTINOTRICHIA IN THE PHILIPPINES ${ }^{1 \text { ? }}$
}

\author{
Paciente A. CORDERO, Jr. ${ }^{2)}$ \\ Seto Marine Biological Laboratory
}

With Text-figures $1-3$

\begin{abstract}
The phytogeographical distribution of Actinotrichia fragilis (Forsskål) Boergesen (Chaetangiaceae, RHODOPHYTA), a monotypic alga, is presented. The writer suggests that the center of divergence for this plant is the tropical part of western Pacific, following that of Galaxaura, its closest relative among the members of family Chaetangiaceae. This supposition is based on the fact that the number of species of genus Galaxaura decreases on Oceanic islands in the Pacific and at localities in the Indian Ocean. The western-most boundary of Actinotrichia is Madagascar, the eastern-most Tahiti, the southern-most, North Australia (above the Tropic of Capricorn), and the northern-most, in Sado Island, Gentral Japan.

Likewise, notes on its morphology and brief nomenclatural history are included in this paper.
\end{abstract}

For years, I have been exploring the marine algal flora of the Philippines. The study, though in large taxonomic, has in effect provided him with ample distributional data of some algae. One of the interesting taxa in these is Actinotrichia fragilis (Chaetangiaceae, Nemaliales, Rhodophyta), a red alga which is extensively distributed in the Philippines.

Early works by Montagne (1844), Dickie (1876), and Weber van Bosse (1921) deal with the Philippine species of Actinotrichia under the old binomial Act. rigida. Incidentally, later records, viz. Menez (1961), Domantay (1961), etc., based on Philippine materials are incomplete when they are compared with those available at present as to the algal flora of the coasts. However, by compiling the results of personal efforts and communications for years, the distribution of Act. fragilis in the Philippines has become now clear to be documented.

Additional results of the distributional studies of the plant in the Philippines have urged the writer to review the probable mechanism of dispersion, that has established and maintained the present distribution in the country. And this, in turn has led me to the phytogeographical considerations of the species.

1) Contributions from the Seto Marine Biological Laboratory, No. 605. Presented at the 40th Annual Meeting/Symposium of the Botanical Society of Japan, Osaka, November 1-3, 1975.

2) Office Address : Botany Division, Philippine National Museum, Rizal Park, Manila, PHILIPPINES.

Publ. Seto Mar. Biol. Lab., XXII (5), 267-276, $1975 . \quad$ (Article 17) 


\section{Distribution Survey in the Philippine Waters}

Actinotrichia fragilis inhabits the intertidal zone of a relatively hard substratum, and has been found from the Red Sea (Type locality), Indian and Pacific Oceans (Sonder 1871; Askenasy 1888, etc.).

In the Philippines, Act. fragilis is generally found in exposed bays, protected coves and inlets and other sites along the coasts of the South China Sea and Pacific Ocean (Cordero 1973) as well as in the inland waters (Reyes 1972). Since 1963, I have surveyed the algal populations of the waters surrounding the Philippine Archipelago, and found that this alga grows generally in association with other algae such as Galaxaura spp., Halimeda spp., Codium spp., Padina spp., Hydroclathrus clathratus,

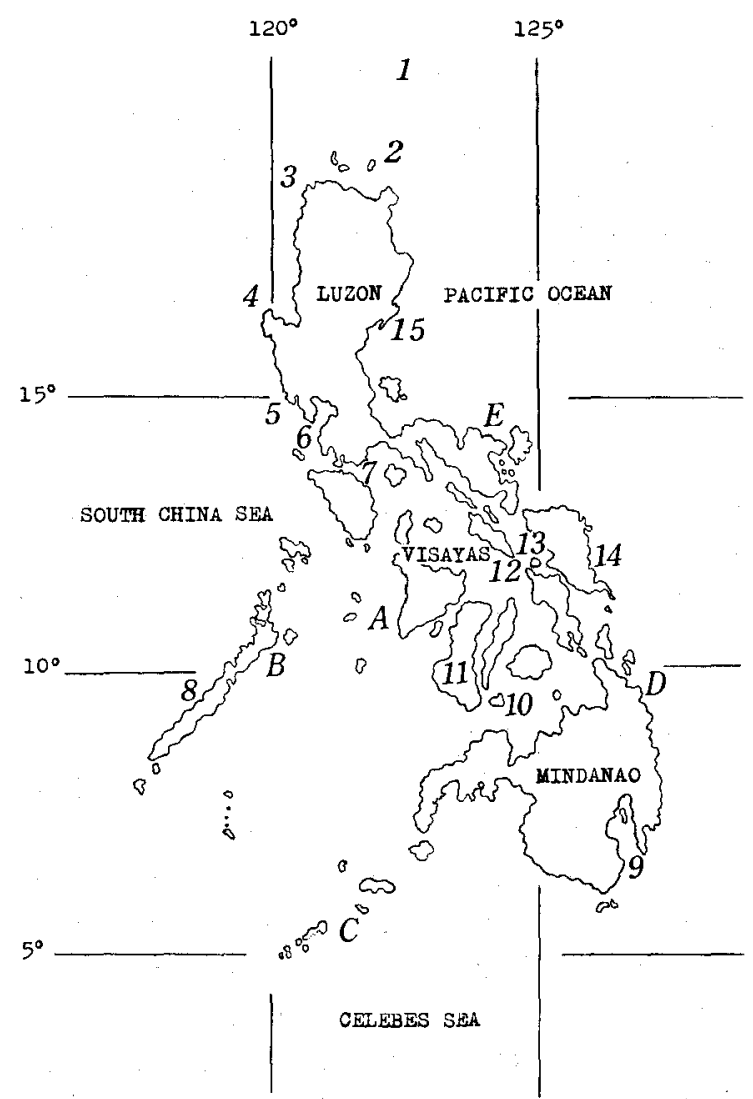

Fig. 1. The Philippine Archipelago, showing the distribution of Act. fragilis cited in the text. (1) Batanes; (2) Camiguin; (3) Ilocos Norte; (4) Pangasinan; (5) Bataan; (6) Corregidor; (7) Oriental Mindoro; (8) Palawan; (9) Davao; (10) Siquijor; (11) Negros Oriental; (12) Biliran; (13) Western Samar; (14) Eastern Samar; (15) Quezon. Those with capital letters indicate the areas where Act. fragilis has been confirmed to form part of the local flora, thus: A, Panay Island; B, Eastern Palawan; C, Sulu; D, Surigao; E, Catanduanes or Bicol Region. 
to mention the more common ones. These surveys included the northern Philippines (Batan and Sabtang islands); Balintang Channel (Camiguin island group); South China Sea (Ilocos Norte and Pangasinan); Sulu Sea (Palawan and Davao); Pacific coast (Cagayan, Quezon, and Eastern Samar); and the inland waters (Oriental Mindoro, Western Samar, and Biliran Island). The observations from these fieldtrips have been combined with published records and personal observations of several people to present a detailed listing of the locations of Act. fragilis on the coast of the Philippines (Fig. 1 and Table 1).

In northern Philippines, here represented by the islands of Batan and Sabtang, Act. fragilis is found in protected bays and inlets, but not in many of these on the exposed coast or at places affected by inflow of freshwater even in adequately protected

Table 1. Records of Act. fragilis in the Philippines.

\begin{tabular}{|c|c|c|}
\hline & Location & Fieldworks and other sources \\
\hline \multicolumn{3}{|c|}{ I. Northern Philippines: } \\
\hline & Batan Is., Batanes & Cordero et al., this study, 1964 \\
\hline & Sabtang Is., Batanes & Cordero et al., this study, 1965 \\
\hline \multicolumn{3}{|c|}{ II. Balintang Channel: } \\
\hline & San Pioquinto, Camiguin Is., & Cordero et al., this study, 1964 \\
\hline & Cadadalman, Camiguin Is., & Tanaka, 1964 \\
\hline & Palaui Is., Cagayan & Cordero et al., this study, 1973 \\
\hline \multicolumn{3}{|c|}{ III. South China Sea: } \\
\hline & Currimao, Ilocos Norte & Gutierrez, 1960 \\
\hline & Burgos, Ilocos Norte & $\begin{array}{l}\text { Gutierrez \& Espiritu, } 1970 ; \\
\text { Cordero et al., this study, } 1973\end{array}$ \\
\hline & Bolinao, Pangasinan & Cordero et al., this study, 1966 \\
\hline & Hundred Islands, Pangasinan & Gutierrez, 1960 \\
\hline & Limay, Bataan & Velasquez, 1968 \\
\hline & Corrigidor Island & Velasquez, 1968 \\
\hline \multicolumn{3}{|c|}{ IV. Sulu Sea: } \\
\hline & Quezon, Palawan & $\begin{array}{l}\text { Cordero et al., this study, } 1963 \text {; } \\
\text { Reynoso, } 1971\end{array}$ \\
\hline & Tomalbong, Quezon, Palawan & Mendoza \& Espiritu, 1964 \\
\hline & Malalag, Davao & Velasquez et al., 1962 \\
\hline & Talikud Is., Davao & Cabrera, 1973 \\
\hline \multicolumn{3}{|c|}{ V. Pacific Cioast: } \\
\hline & Sta. Ana, Cagayan & Cordero et al,, this study, 1973 \\
\hline & Casiguran, Quezon & Gutierrez et al., 1974 \\
\hline & Dipaculao, Quezon & Gutierrez et al., 1974 \\
\hline & Borongan, Eastern Samar & Cordero et al., this study, 1973 \\
\hline & Marabut, Eastern Samar & Cordero et al., this study, 1973 \\
\hline \multirow[t]{6}{*}{ VI. } & Inland Water: & \\
\hline & Pto. Galera, Oriental Mindoro & $\begin{array}{l}\text { Cordero et al., this study, } 1967 \\
\text { and } 1972\end{array}$ \\
\hline & Catbalogan, Western Samar & Cordero et al., this study, 1973 \\
\hline & Biliran Island, Leyte & $\begin{array}{l}\text { Cordero et al., this study, } 1967 \\
\text { and } 1972\end{array}$ \\
\hline & Dumaguete, Negros Oriental & Reyes, 1968 \\
\hline & Siquijor Island & Reyes, 1972; Gutierrez et al., 1974 \\
\hline
\end{tabular}


environments (Valugan to Uyugan and Mahatao, respectively). This is due to its less resistance against the extreme water agitation throughout the year and the lower salinity.

The coast of Camiguin island from San Pioquinto to Cadadalman, off the Balintang Channel, is rugged and exposed to the open sea, and here the South China Sea and Pacific Ocean converge. Actinotrichia is usually found associated with red Galaxaura fastigiata and Gal. subverticillata, brown Padina spp., Sargassum spp., and Dictyota dichotoma, and green Halimeda spp., Udotea spp., and Avrainvillea capituliformis Tanaka, in this region except for a narrow strip of mangrove swamp.

The western coast of Luzon mainland from Ilocos Norte down to Pangasinan facing the South China Sea, contains scattered growths of Act. fragilis, though the works of Galutira and Velasquez (1963), Menez (1961), and Domantay (1961), based on the algal flora of the two Provinces failed to include this alga. Probably, the constantly moving water and predominantly hard shore substratum of the area provide favorable habitats for this chactangiaceaous alga. In 1966 and 1972, I visited the stations mentioned by the above workers and found that isolated populations of Act. fragilis were very evident in several of these, especially most atrikingly in the vicinity of Bolinao, Pangasinan. It is believed that this red alga is also present in other more in-accessible areas. Likewise, the shores of Bataan, Corregidor, and Batangas are definitely populated with Actinotrichia, although no mention was made by Velasquez et al (1971).

Further southerly, the coastal shores of Quezon, Palawan and its islets facing the north-western Sulu Sea, revealed only poorer growths of Actinotrichia. In turbid areas, as might be expected, there is no trace of this alga. There are, however, unconfirmed reports of this alga on the eastern side of Palawan. From the southeastern part of the Sulu Sea, Davao and its islets, this plant has been represented by dried materials kept in the Cryptogamic Herbarium of the University of the Philippines (PUH) and the Philippine National Herbarium (PNH).

The Pacific side of the Philippines, from Sta. Ana, Cagayan and Casiguran, Quezon in the north to Eastern Samar in the south, yielded a few patches of Act. fragilis, though commoner in the latter province. This could be explained by the relatively higher water temperature maintained there all the year round almost steadily, probably brought about by nearly the direct effect of the North Equatorial current. Quantitavely, the relative largeness of the Actinotrichia stock on the Pacific coasts as compared with that on South China Sea coasts is very evident. There could be some other favorable ecological factors other than the higher water temperature.

Finally, the inland waters of the Central Philippines, or the island-scattered Visayan Region and part of southern Luzon, showed an extensive growth of Actinotrichia. I visited and botanized Puerto Galera, Oriental Mindoro, site of the Biological Station of the University of the Philippines, in 1967 and 1972, and there confirmed the presence of this alga. My findings were well supplemented with numerous herbarium materials deposited in the PUH. In the Province of Western Samar from Catbalogan to Villareal as well as Dumaguete, Negros Oriental and the 
island sub-Province of Siquijor, Act. fragilis was found to be a common component of the subtidal flora. Southerly is another island sub-Province-Biliran, an area explored twice in 1969 and 1972, isolated growths of this alga were observed in both of these outings. The 1969 collections are shown in Cordero's (1973) floristic account of the island. There are also unconfirmed reports of Actinotrichia from the Panay island, Cebu, and Bohol Provinces.

\section{Phytogeographical Considerations}

The distribution of Act. fragilis in the Philippines and adjacent waters should be attributed to several dispersal mechanisms as in other marine plants, but apparently most effectively to the oceanic current for the distant dispersion. The genus Actinotrichia is distributed widely from the Red Sea, through the tropical regions of the Indian Ocean to the Pacific west of $150^{\circ} \mathrm{W}$, but extending northerly to $35^{\circ} \mathrm{N}$ on the Japanese coast in the north-western part of the latter. It has been recorded from the Red Sea, Madagascar (Sonder 1871); Northern Australia and nearby islands of Tonga, Tahiti, and Sandwich (Sonder 1871, Askenasy 1888, and Weber van Bosse, 1921); Micronesia, viz, Truk and Mariana (Tsuda 1969, 1972), Caroline Islands (Trono 1969); the Philippines (Montagne 1844; Dickie 1876; Weber van Bosse 1921; Reyes 1972 and Cordero 1973); China (Tseng 1969); Taiwan (Chiang 1962); Vietnam (Dawson 1954); and, Japan (Okamura 1916, 1936; Segawa 1930, 1956; Yamada and Tanaka 1938; and, Noda and Kitami 1971). This distribution contrasts with those of other genera of Family Chaetangiaceae, such as Scinaia, Gloiophloea, Pseudoscinaia, Pseudogloiopholea, and Whidbeyella, which range from the temperate, subtropical to tropical regions but never so widely as Actinotrichia nor tolerate higher temperatures as this genus. Only the genus Galaxaura of the same family has a wide and more or less identical distributional pattern in the tropical waters as Actinotrichia, though it is less tolerable to higher temperatures and its distribution is restrictive.

The local distribution and abundance of Actinotrichia should depend upon the environmental factors special to respective areas. On the other hand, the extensive dispersion in a large scale must be related with the history of the seas and phylogenetic development of the genus, if the present distribution has been achieved in a very long time. This is, however, unlikely, when the distribution of the genus is compared with those of the closely related genera. Rather the extensive distribution seems to be a notable feature of the genus that its spores can be borne to a distance by ocean currents of higher temperatures. If this is true, the present status of distribution may be achieved rather in a much shorter time.

It is very difficult to see from what part of the Indo-Pacific the genus has been dispersed. Only it is evident that the distribution in the Japanese waters is attributed to the Kuroshio flowing northerly from off the east coast of Luzon island and that the occurrence in the Red Sea has been brought about by the surface current flowing northerly from the Strait of Babel Mandeb. Although our knowledge of 
algal flora is not even throughout the Indo-Pacific, the genus Galaxaura is most richly diverged in the waters from the Malay Archipelago to the Japanese Islands. The number of species is decreasing on Oceanic islands in the Pacific and at localities in the Indian Ocean. This seems to allude that the center of divergence of the genus Galaxaura is possibly the tropical west Pacific. This might be applicable to Actinotrichia, the genus related to Galaxaura most closely. Then, the rather common occurrence of the genus in the Philippine waters may be accepted as quite natural.

\section{Morphological Observations}

Actinotrichia fragilis (Forsskål) Boergesen.

Figs. 2-3.

1932: 6, pl. 1, fig. 4; Tseng 1941: 97, fig. 8 a-e; Dawson 1954: 416, fig. 28b; Trono 1969: 45; Reyes 1975: 152; Noda and Kitami 1971: 37; Cordero 1973: 28.

The plant is definitely saxicolous, forming globose mass, rigid, purplish-red to yellowish or rarely greenish, to $10 \mathrm{~cm}$ tall or more; cylindrical branches to $1 \mathrm{~mm}$ in diameter, densely and regularly dichotomous, with patent or acute axils, calcified, ending in blunt apices; projecting assimilatory filaments or 'hairs' forming whorls, short, simple or may be branched; hairs of single row of short cylndrical cells with
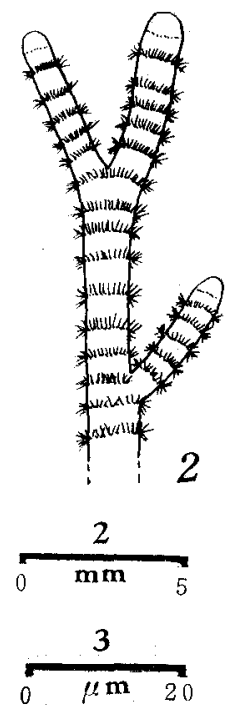

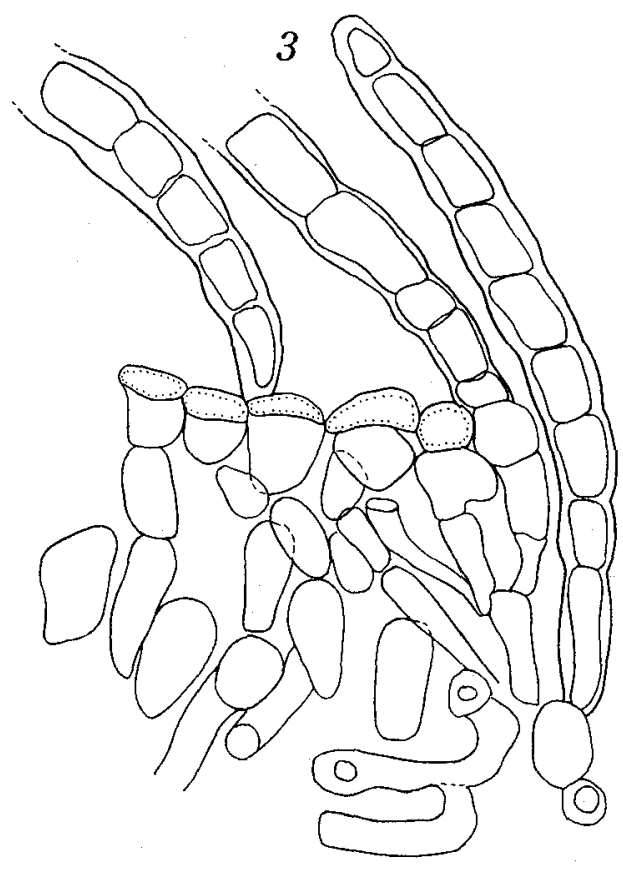

Figs. 2-3. Actinotrichia fragilis (Forssk.) Boergesen.

2. Upper portion of a plant.

3. Small portion of the cortex from the margin cut through a fascicle of extended assimilatory filaments. 
blunt apices, usually deciduous basally in older branches. The numerous specimens examined failed to confirm the reproductive structure.

The color, height and presence or absence of 'hairs' are affected by the ecological factors and vary with age and seasons.

Type: in Forsskål Herbarium, Botanical Museum, Copenhagen.

Type locality: Red Sea

Materials examined:

ILOCOS NORTE: PNH 41457, Gaang Bay, Currimao, H.G. Gutierrez, 4/26/60; PNH 41475, Bobon Bay, Burgos, H.G. Gutierrez, 4/28/60; PNH 103625, Bobon Bay, Burgos, H.G. Gutierrez and R. Espiritu, 6/17/70.

PANGASINAN: PNH 41395, Quezon Is., Hundred Islands, Alaminos, H.G. Gutierrez, 4/13/60; PNH 96795, S. Ilog, Balingasay, Bolinao, 5/17/66; PNH 96792 and PNH 96789, Mantapopo, Bolinao, 5/16/66.

CAGAYAN: PNH 109289, NW San Pioquinto, Camiguin Is., T. Tanaka, 11/ 19/64.

QUEZON: PNH 115493, San Ildefonso Cove, Casiguran, H. G. Guiterrez et al., 4/74, PNH 115403, Dinaglianan, Dipaculao, H.G. Gutierrez et al., 4/74.

BATAAN: GTV 6521, Sitio Silay, Limay, 8/5/68.

CORREGIDOR: GTV 6434, Corregidor Island, 4/3/68. (Puerto Galera)

ORIENTAL MINDORO: PNH 109201, Medio Is., 6/19/72; PNH 109147, Palanan Pt., 6/22/72; PNH 109204, Honduras, 6/20/72; PNH 109196, Dolaruan, 6/16/72; PNH 109179, Manik-nik, 6/23/72; PNH 109159, Boquete, 6/23/72; PNH 109137, Balantigue, 6/22/72; PNH 109205, Balateros, 6/22/72; PNH 109183, Licot, 6/15/72; PNH 109139, Palanan Pt., 6/22/72; GTV 5279, San Isidro, 5/2/62.

SIQUIJOR: PNH 112047, Cangalwang, Siquijor Is., A.Y. Reyes, 5/24/72; PNH 116411, San Juan, Siquijor Is., H.G. Gutierrez et al., 3/74; PNH 114478, Solongon, Siquijor Is., H.G. Gutierrez et al, 2/74.

NEGROS ORIENTAL: PNH 111884, Banilad, Dumaguete, A.Y. Reyes, $6 / 10 / 68$.

BILIRAN: PNH 97637 and PNH 97636, Capinyahan Is., Almeria, 5/10/67; PNH 97649, Look-Poro, Almeria, 5/12/67; PNH 97667, B. Talahid, Almeria, 5/17/67; PNH 97697, Bo. Jamurawon, Almeria, 5/22/67; PNH 109452, Caibiran, 12/9/72; PNH 109456, Manolapi, 12/10/72; PNH 109492, Tingcasan, Kawayan, 12/14/72; PNH 109486, Cogon, Tingcasan, Kawayan, 12/13/72; PNH 109346, Binohangan, Kawayan, 11/25/72; PNH 109480, Tinago, Kawayan, 12/12/72; PNH 109339, Bariis, Caibiran, 11/24/72; PNH 109415, Santarin, Culaba, 12/4/72; PNH 109334, Tomalistis Sur, Caibiran, 11/23/72; PNH 109360, Guindolngan, Caibiran, 11/27/72 ; PNH 109371, Manlabang, Caibiran, 11/28/72; PNH 109384, Tomalistis Norte, Caibiran, 11/29/72; PNH 113922, N. Almeria Bay, Almeria, 5/10/67.

EASTERN SAMAR: PNH 112488 and PNH 112481, Legaspi, Marabut, 5/73; PNH 112392, Punta Maria, Borongan, 5/73; PNH 112442, Ando Island, Borongan, 5/73; PNH 112425 and PNH 112405, Divinubo Is., Borongan, 5/73; PNH 112475, Caläouayan, Marabut, 5/73. 
WESTERN SAMAR: PNH 112336, Punobulo Is., Basey, H.G. Gutierrez et al., 4-5/70.

PALAWAN: PNH 91407, Tomalbong, Quezon, D.R. Mendoza and R. Espiritu, 4/28/64; PNH 113974, Quezon, E.J. Reynoso, 8/71.

DAVAO: PNH 112507, Dadatan, Sta. Cruz, Talikud Is., J. Cabrera, 4/73; GTV 5452, GTV 5248, and GTV 5229, Malalag, 5/9/63, 4/18/62, and 4/21/62, respectively.

Remarks on the materials examined.

The materials bearing the initials GTV or Gregorio T. Velasquez, are kept in the Cryptogamic Herbarium, University of the Philippines. Those from the PNH are collections of this writer either singly or in cooperation with the staff of the Botany Division, Philippine National Museum, unless otherwise indicated.

\section{Synonymy}

The oldest name known for the species under consideration is Corallina indurata, given by Ellis and Solander (1786), to identify their material probably of 'unknown' taxonomic position. The next name was created by Kutzing (1858), Galaxaura indurata, a more or less accurate assignment of the genus. Lamouroux (1816) retained the generic assignment made by Kutzing but combined it with another species-Gal. rigida.

In 1842, Decaisne revised Lamouroux's work by assigning the plant to the genus Actinotrichia. Thus, his new binomial was Act. rigida, retaining the specific name initially used by Lamouroux. For several years the present plant has been identified under this scientific name.

However, an earlier work of Forsskål (1775) cites the present plant under the binomial Fucus fragilis. Finally, this binomial changes was resolved by Boergesen (1932), following a revision of Forsskål's and previous taxonomic assignments. He (Boergesen), adopted Decaisne's genus for the plant, while retaining the specific name of Forsskal. Thus, the correct binomial for this plant, following the rules of International Botanical Nomenclature, is Actinotrichia fragilis (Forsskål) Boergesen.

The synonymy of the species follows:

Actinotrichia fragilis (Forsskål) Boergesen 1932: 6, pl. 1, fig. 4 .

Fucus fragilis Forsskàl 1775: 190.

Act. rigida (Lamouroux) Decaisne 1842: 118.

Galaxaura rigida Lamouroux 1816: 265, tab. 8, fig. 4.

Galaxaura indurata Kutzing 1858: 14, tab. 31, fig. 1.

Corallina indurata Ellis \& Solander 17786: 116.

\section{Acknowledgement}

For loan of materials and continued advices hearty thanks are due Dr. Gregorio T. Velasquez, Emeritus Professor, University of the Philippines, Dr. Takesi Tanaka, 
Emeritus Professor, Kagoshima University, Japan, and Dir. Godofredo L. Alcasid, Philippine National Museum; my colleagues who helped me gather enormous field data/materials and provided wholesome company headed by H.G. Gutierrez, R.M. del Rosario, D. Madulid, E.J. Reynoso, R.E. Espiritu and F. de la Cruz as well as W. Vendivil and I. Masayon, then working with me on a project financed by the National Research Council of the Philippines; Dr. Takasi Tokioka, Director, Seto Marine Biological Laboratory, Kyoto University, for critically reading the manuscript and valuable suggestions especially on phytogeography; for the same institution for unlimited access to its research and library facilities; and, finally the Philippine Government thru its National Museum and National Research Council for the financial assistance accorded during the course of this investigations and for having been granted another leave of absence from my official duties for the second time.

\section{LITERATURE CITED}

Askenasy, E. 1888. Algen...in Die Forschungereise S.M.S. "Gazelle” 1874 bis 1876 unter Komando... Bot. 4: 1-50, pls. 4-12. E. Siegfried, Mittler et Sohn, Berlin.

Boergesen, F. 1932. A revision of Forsskal's algae mentioned in Flora Aegyptiaco-arabica and found in his herbarium in the Botanical Museum of the Univ. of Copenhagen. Dansk Bot. Arkiv. 8(2): $1-15,1 \mathrm{pl}$.

Chiang, Y.M. 1962. Marine algae of Northern Taiwan (Rhodophyta). Taiwania 8: 143-165.

Cordero, Jr., P.A. 1973. On the Marine Algae of Biliran Island (Leyte) and Vicinities, Central Philippines-I. Leyte-Samar Studies 7(1): 15-37. Divine Word Univ. Publ., Tacloban City, Philippines.

Dawson, E.Y. 1954. Marine algae in the Vicinity of the Institut Oceanographique de Nha Trang, Vietnam. Pac. Sci. 8(4): 373-469, 63 figs.

Decaisne, M.S. 1842. Memoire sur les corallines ou polypiers calcifiers. Ann. Sci. Nat. II, Bot. 18: 92-126.

Dickie, G. 1876. Algae, Chiefly Polynesian in Contributions to the botany of the expedition of the H.M.S. "Challenger", Jour. I inn. Soc. (Bot.) 15: 235-246.

Domantay, J. 1961. An ecological survey of the marine vegetation of the Hundred Islands and Vicinity. Phil. Jour. Sci. 90: 271-295.

Ellis, J. and D. Solander 1786. The natural history of many curious and uncommon zoophytes, collected from various parts of the globe... by John Ellis...systematically arranged and described by Daniel Solander, etc. 208 pp. London.

Forsskål, P. 1775. Flora aegyptiaco-arabica...Post mortem auctoris edidit C. Niebuhr, $33+x x v i+299$ pp. Muller, Hauniae.

Galutira, E.C. and G.T. Velasquez 1963. Taxonomy, distribution and seasonal occurrence of edible marine algae in Ilocos Norte. Phil. Jour. Sci. 92: 483-522, 9 pls.

Kutzing, F.T. 1858. Tabulae phycologicae...8: 1-48, 100 pls. W. Kohne, Nordhausen.

Lamouroux, M.S. 1842. Histoire des polypiers coralligenes flexibilies, vulgaire-nommes zoophytes. 460 pp. Caen.

Menez, E. 1961. The marine algae of the Hundred Islands, Philippines. Phil. Jour. Sci. 90: 37-81.

Montagne, C. 1844. Plantae cellulares guas in Insulis Philippinensibus a cl. Cumming Collectae... Lond. Jour. Bot. $3: 658-662$.

Noda, M. and T. Kitami 1971. Some species of Marine Algae from Echigo Province facing the Japan Sea. Sci. Rep. Niigata Univ., ser. D (Biology), 8: 35-52.

Okamura, K. 1916. Icones of Japanese Algae. 4: 30-31, pl. GLVIII, figs. 17-19. 1930. On the algae from the Island Hatidyo. Repr. Rec. Oceanogr. Works Japan 2: 92110,5 pls. 
21-38.

1934. Notes on the Algae collected near Kanayama, Pref. of Wakayama. Jour. Bot. 10(3): 1936. Nippon Kaiso-shi. 964 pp.

Reyes, A.Y. 1970. A Survey of the Littoral Benthic Algae of the Coastal Areas of Dumaguete City. Phil. Jour. Sci. 99(3-4): 131-163.

Segawa, S. 1930. On the marine algae of Susaki, Prov. Idzu and its vicinity. Sci. Pap. Inst. Algol. Res. Fac. Sci. Hokkaido Imp. Univ, 1(1): 59-90.

1956. Coloured Illustrations of the Seaweeds of Japan. 175 pp., Osaka.

Sonder, W. 1871. Die Algen des Tropischen Australiens. 73 pp., 5 tabs.

Trono, Jr., G.C. 1969. The Marine Benthic Algae of the Caroline Islands, II. Micronesica 5(1): 25-119.

Tseng, C.K. 1941. Studies on the Chaetangiaceae of China. Bull. Fan Inst. Biol., Bot. Ser. 11(2): 82-116, 13 pls.

Tsuda, R.T. 1969. A Preliminary Checklist of Marine Benthic Algae in the Eight Mariana Islands. Division of Biosciences and Marine Studies, University of Guam. 11 pp. (Memeographed).

_ 1972. Some Marine Benthic Algae from Truk and Kuop, Caroline Islands. Atoll Res, Bull. No. 155.

Velasquez, G.T., D.F. Cornejo, A.E. Santiago, and L.B. Arcega 1971. Algal Communities of Exposed and Protected Marine Waters of Batangas and Bataan. Phil. Jour. Sci. 100: 1-40, 14 pls.

Weber van Bosse, A. 1921. Liste des alga du Siboga 2: 1-207, pl. 6, figs. 1-2.

Yamada Y. and T. Tanaka 1938. The marine algae fromtthe Island of Yonakuni. Sci. Pap. Inst. Algol. Res. Fac. Sci. Hokkaido Imp. Univ. 2(1): 53-86. 